\title{
Horváth Marianna
}

\section{A kiskereskedelmi logisztikai stratégiai modellek kritikai elemzése}

Horváth, Marianna: Critical analysis of logistics strategy models in retailing

Logistics is key for retailing because product availability is a significant element of customer service and has key importance for competitiveness as well. In the following I would like to demonstrate the strategic retail models of the academic literature and give different points of view on retail logistics. Then, with the help of an empirical study I will elaborate on the model of Hungarian retail logistics.

Keywords: retailing, logistics, strategy, crisis

\section{ÖSSZEFOGLALó}

A kiskereskedelem számára a logisztika kulcsfontosságú, hiszen a termék rendelkezésre állása a vevőkiszolgálás sarkalatos pontja illetve a versenyképesség egyik meghatározó eleme is. A következőkben a nemzetközi szakirodalomban fellelhető kiskereskedelmi stratégiai modelleket kívánom bemutatni illetve a kiskereskedelmi logisztika értelmezésére mutatok rá. Majd egy empirikus kutatás segítségével a magyar kiskereskedelemre jellemző modellt is részletezem.

Kulcsszavak:

kiskereskedelem, logisztika, stratégia, válság

\section{Bevezetés}

A korszerű ellátási láncok akkor maradnak versenyképesek, ha képesek a fogyasztói szokások változásaira időben reagálni (a földrajzi távolságok és összetett elosztórendszerek ellenére). Ezekben a hálózatokban a kiskereskedelem érzékeli leghamarabb és leginkább közvetlenül ezeket a változásokat, hatásokat (például divathatás, szezonalitás, akció miatt keresletnövekedés).

Gudehus és Brandes (1997) szerint a kiskeres- kedelem alapvető kompetenciája a logisztika. Mulhern (1997) szerint is a kiskereskedelem "ereje" leginkább a logisztikai folyamatokon múlik, illetve az ehhez kapcsolódó információáramláson. A kiskereskedelemhez kapcsolódó logisztikai folyamatok leginkább a termékek rendelkezésre állását tűzik ki célul a $6 \mathrm{M}$ elv megvalósulása mellett.

\section{A KISKERESKEDELMI LOGISZTIKA ÉRTELMEZÉSE}

A kiskereskedelmi logisztika a kilencvenes évektől értékelődött fel (Kotzab, Schnedlitz, 1999). A kiskereskedelemhez kapcsolódó logisztikai folyamatok egy komplex rendszer részei, mely az áruáramláshoz kapcsolódik illetve a kapcsolódó információkhoz, melyek nagymértékben összefüggnek a belső és külső tényezőkkel, melyet a következő ábra szemléltet.

A különböző faktorok rámutatnak a főbb logisztikai területekre, melyek a kiskereskedelemben jellemzőek. Az ellátási lánc szemlélet alapján fontos a beszállítói hálózat, a versenyképesség és a technológiai környezet is (a kiskereskedelemben az IT eszközök használata szükségszerű). $A$ belső faktorok részben a kategóriamenedzsment területéhez kapcsolódnak.

A kiskereskedelem szereplői fokozottan érde- 
1. ábra: A kiskereskedelmi logisztika faktorai

\begin{tabular}{|c|c|c|c|c|}
\hline \multicolumn{5}{|c|}{$\begin{array}{c}\text { Kiskereskedelmi logisztika } \\
\text { döntési paraméterek, költségek, szolgáltatások }\end{array}$} \\
\hline \multicolumn{3}{|c|}{ Külső faktorok } & \multicolumn{2}{|c|}{ Belső faktorok } \\
\hline $\begin{array}{l}\text { Beszállítók } \\
\text { hálózata }\end{array}$ & Verseny & $\begin{array}{l}\text { Technológiai } \\
\text { környezet }\end{array}$ & Elhelyezkedés & $\begin{array}{l}\text { Termék- } \\
\text { választék }\end{array}$ \\
\hline \multicolumn{5}{|c|}{$\begin{array}{l}\text { költségek - logisztikai döntéshozatal - szolgáltatások } \\
\text { készletezés } \\
\text { raktározás } \\
\text { szállitás } \\
\text { csomagolás } \\
\text { rendelésmenedzsment }\end{array}$} \\
\hline
\end{tabular}

forrás: Toporowski 1996

keltek beszállítóik logisztikai rendszereiben, folyamataiban. A beszállító logisztikai rendszerének hiányosságait a láncban következő kiskereskedők direkt módon tapasztalják meg. A kiskereskedelmi vállalkozások integrálhatják logisztikai rendszereiket beszállítóikkal, így minimalizálhatják a működési hibákat és a szereplők potenciális előnyöket élvezhetnek, mint például a költségek csökkentése, vevőkiszolgálási színvonal növelése (Gustafsson et al., 2009).

A logisztikai menedzsment a logisztikai mix kapcsolatán alapul (2. ábra). A raktározás, készletezés, szállítás, csomagolás és kommunikáció kölcsönösen függnek egymástól. A kiskereskedelem gyors reagálási készsége nagymértékben függ a beszállítóktól, azonban, ha a kiskereskedő nem megfelelően reagál a fogyasztói szokások változására, kihat a beszállítókra, mint általában az ellátási hálózatokban (Gustafsson et al., 2009).

A logisztikai mix valamely elemének elégtelensége kihat az ellátási lánc valamennyi tagjára is, veszélyeztetve a lánc versenyképességét.
A kiskereskedelmi logisztika célja, hogy a fogyasztók által igényelt termékek teljes mértékben rendelkezésre álljanak a boltok polcain (Farahani et al., 2011). A termékek rendelkezésre állása a központi elem, de ehhez szükséges a fogyasztói magatartás ismerete, mikor és hol álljanak rendelkezésre a termékek. Manapság az értékesítési pontok menedzsmentje, elhelyezése is nagyon fontos terület - akár a franchise rendszer kialakítása (Farahani

et al., 2011).

A kiskereskedelemhez kapcsolódó logisztikai folyamatok egy részét gyakran helyezik ki a vállalatok. Az outsourcing főként a szállítás, raktározás esetében gyakori. Leginkább a professzionális szolgáltatás, az alapvető képességekre való koncentrálás az indok a kihelyezés esetében (Fernie-Sparks, 2009).

\section{1. táblázat A kiskereskedelmi logisztikai mix összetevői}

\begin{tabular}{|c|c|}
\hline Elem & Leírás \\
\hline raktározás & $\begin{array}{l}\text { Lehetnek raktárak, elosztó központok vagy bolti raktár- } \\
\text { helyiségek. A kiskereskedők raktározási célja a kereslet } \\
\text { közvetlen kielégítése vagy a keresletingadozásra történő } \\
\text { reagálás. Léteznek raktárnélküli megoldások is. }\end{array}$ \\
\hline készlet & $\begin{array}{l}\text { A kiskereskedők különböző mértékben tartanak készle- } \\
\text { teket. A stratégia összpontosít a készletek nagyságára, } \\
\text { összetételére és elhelyezésére. }\end{array}$ \\
\hline szállítás & $\begin{array}{l}\text { A szállitásszervezés a kereslet és kínálat fizikai összehan- } \\
\text { golása. A kiskereskedők lehetőség szerint menedzselik } \\
\text { ezeket a folyamatokat. }\end{array}$ \\
\hline $\begin{array}{l}\text { egységkép- } \\
\text { zés, csoma- } \\
\text { golás }\end{array}$ & $\begin{array}{l}\text { A kiskereskedők feladata a termékek előkészítése a fo- } \\
\text { gyasztói igényeknek megfelelően. A nagyobb csomago- } \\
\text { lási egységekből fogyasztói vagy gyűjtőcsomagolást kell } \\
\text { a boltokban kihelyezni. }\end{array}$ \\
\hline $\begin{array}{l}\text { kommuni- } \\
\text { káció }\end{array}$ & $\begin{array}{l}\text { Az információáramlás kapcsolódik a keresleti és kínálati } \\
\text { oldalhoz is (készletnagyság, árak, fogyás mértéke és ösz- } \\
\text { szetétele). A megfelelő információáramlás a logisztikai } \\
\text { folyamatok szervezésének alapja. }\end{array}$ \\
\hline
\end{tabular}

Forrás: Gustafsson et al., 2009, Fernie-Sparks, 2009 
Meglehetősen gyakori megoldás az integrált logisztikai információs rendszer, mely a POS rendszer segítségével segíti a fogyasztói kosár tételes megismerését. $A$ leginkább integrált rendszerek esetében a real-time információáramlás közvetlenül hat a termelésre (SkjottLarsen et al., 2007).

Ray (2010) a kiskereskedelmi logisztika funkciói közé sorolja a szállításszervezést és a tárolásmenedzsmentet illetve a modern felfogás szerint a kiskereskedelem piacának, a logisztikai szolgáltatók menedzselését, a kiskereskedelmi múködés sajátos problémáit, az IT szerepét a kiskereskedelemben és a zöld kiskereskedelmet is.

A kiskereskedelem sajátos működési problémái a termék-hiányban és okaiban is jelentkeznek. A hiány fogyasztói lopás, belső dézsmálás, folyamat-hibák és beszállítói csalások miatt keletkezik, mely a logisztikai folyamatokra, készletmenedzsmentre is hatással van (Ray 2010). A szerző szerint a hiány keresztfunkciójú probléma, mely a vállalaton belüli és vállalatok közötti kapcsolatokból adódik, felelősségi körökből. A funkciók (logisztika, beszerzés, marketing, HR stb.) célja mások mellett a hiány csökkentése is (Ray 2010).

Egy másik felosztás alapján a kiskereskedelmi logisztika egy komplex logisztikai rendszer, amely magába foglalja az áru- és információáramlást, ezek a folyamatok pedig a külső és belső tényezőktől függnek. Külső tényező a beszállítók száma, nagysága, a beszerzési logisztika jellemzői, a versenyképes működési forma mellett az IT és egyéb környezeti faktorok (Kotzab, Bjeree, 2005). Empirikus kutatások alapján egyértelműen kimondható a kapcsolat a kiskereskedő és beszállító illetve a kiskereskedelem logisztikai rendszere között. A sikeres kiskereskedelmi logisztikai rendszer nem csak a megfelelő készleteken múlik (Kotzab and Reutterer 2000), hanem az információs technológiai megoldások is (Fernie et al., 2009) zöld- ség-kiskereskedelemhez kapcsolódó kutatásaiban ezt a változást a tranzakció-alapú logisztikai folyamatokról történő áttérésnek nevezi a kapcsolatalapú logisztikára. A növekvő számú kiskereskedők beszállítóikat infokommunikációs megoldásaik alapján is értékelik.

A beszerzési és disztribúciós folyamatok tartoznak a belső faktorok közé, melyek alapvetően meghatározzák kiskereskedelmi logisztikai rendszer outputjának minőségi és mennyiségi jellemzőit.

\section{A LOGISZTIKA SZEREPE \\ A KISKERESKEDELMI VÁLLALATI STRATÉGIÁBAN}

A kiskereskedelem koncentrál az áruáramlás menedzselésére összehangolva a keresletmenedzsmenttel illetve az információáramlással, mind a vállalaton belül, mind az ellátási lánc tagjai között. Egyrészről a logisztikai stratégia fókuszál a termékválaszték kialakításához és terméktartáshoz kapcsolódó logisztikai folyamatokra illetve az előrelátás, tervezés folyamataira, melyek szorosan kapcsolódnak a gyors reagálási képességhez is, hiszen a kereslet gyorsan változik.

A logisztikai stratégia hatékony alkalmazása elsődleges fontosságú a kiskereskedelemi vállalatok stratégiájának támogatásában és végrehajtásában. Általában először az általános, átfogó vállalati stratégiát alkotják meg, majd a logisztikai stratégát dolgozzák ki, mely segíti az általános célok elérését. A logisztikai stratégia így elsősorban funkcionális támogató rendszerré válik, támogatva a vállalat hazai és/vagy nemzetközi stratégiáját. Azonban a logisztika, mint más vállalati funkciók, új utat nyithat meg a stratégiai cselekvési irányvonalak között, az új lehetőségek láthatósága érdekében elengedhetetlen a logisztikai eszközök stratégiává alakítása (Fabbe-Costes, Colin, 1999). A stratégiai logisztika a stratégiai cselekvések fejlesztése, melyek nem hajthatóak végre alapvető logisz- 
tikai kompetenciák nélkül, miután a logisztika is a kulcsfontosságú tényezők egyikévé válik versenyelőnyként. A 2. táblázat illusztrálja a kiskereskedelmi logisztikai funkció különböző megközelítéseit (Joia, 2003). termékköri lehatárolás nem volt cél, földrajzi viszont igen, a Kelet-magyarországi terület.

A kutatás során a független, franchise-hoz tartozó illetve kiskereskedelmi láncok által müködtetett egységek is a megkérdezettek közé

\section{2. táblázat: A kiskereskedelmi logisztikai stratégia és a stratégiai logisztika összehasonlítása}

\begin{tabular}{|c|c|c|}
\hline & $\begin{array}{l}\text { Kiskereskedelmi } \\
\text { logisztikai stratégia }\end{array}$ & $\begin{array}{l}\text { Kiskereskedelmi } \\
\text { stratégiai logisztika }\end{array}$ \\
\hline Logisztikai megközelítés & Stratégia támogatása & Stratégián alapul \\
\hline Hatás a szervezetre & Javítás, fejlesztés & Változtatás, átalakítás \\
\hline Logisztikai főbb előnyök & $\begin{array}{l}\text { Eszközök a költségcsökkentésre és } \\
\text { ellenőrzésre }\end{array}$ & Kompetitív előnyök \\
\hline Megközelités & Nem tervezett, sürgős & Tervezett, szándékos \\
\hline Időponti megközelítés & Reaktív & Proaktív \\
\hline $\begin{array}{l}\text { A logisztika szerepe a kiskeres- } \\
\text { kedők helyi és/vagy nemzetközi } \\
\text { terjeszkedésére }\end{array}$ & Támogató funkció & Elsődleges fontosságú \\
\hline
\end{tabular}

Forrás: Joia, 2003

A piac dinamikus változásai (több eladó, mint vevő, rövidülő termék-életciklus, globalizálódó piacok) erőteljes hatással voltak a kiskereskedelmi logisztika jelentőségére és jellegzetességeire, mivel a megfelelő termékválaszték már nem elégséges a fogyasztók számára. Mindezek a folyamatok hatást gyakorolnak a kiskereskedelemhez kapcsolódó költségek struktúrájára is. A kiskereskedelem logisztikai folyamatokra történő koncentrálása segíti elő a nyereséges működést és megvéd az ártalmas árháborúktól (Kotzab, Bjeree, 2005), ezért bír stratégiai jelentőséggel.

\section{EMPIRIKUS KUTATÁS A KISKERESKEDELEM LOGISZTIKAI STRATÉGIÁJÁNAK TIPIZÁLÁSÁRA}

Kvantitativ kutatásmódszertan használatával, kérdezőbiztosok segítségével a megkérdezés során 475 kiskereskedelmi egység vezetője illetve tulajdonosa töltötte ki a kérdőiveket.

A kiskereskedelmi egységek kiválasztása egyszerű véletlen mintavétel alapján történt, kerültek, hiszen a magyar kiskereskedelem szerves részét képezi valamennyi tulajdonosi, működtetési forma.

A megkérdezettek többnyire egyetértenek abban, hogy a fogyasztásban kifejezetten jelentős változások mentek végbe az elmúlt néhány esztendőben, illetve valamennyi kiskereskedelmi egységet is érintett a válság. Mindezek a változások elősegítik a kiskereskedelmi logisztikai stratégia szerepének erősödését.

A kiskereskedelmi egységek tulajdoni formája, a bolttípus és a logisztikai stratégia jellegzetességeiben gyenge kapcsolat mérhető a Cramer-féle V mutató alapján.

A szakirodalomban fellelhető releváns modellek, megközelítések alapján a következő koncepciót alakítottam ki. (2. ábra)

A kutatási eredmények alapján a kiskereskedők a csomagolás, egységképzés, a hiány, az értékesítési pontok elhelyezése és a termékelhelyezés elemeit nem sorolják a logisztikai stratégia főbb elemei közé. A reagálási képesség leginkább a válságkezelési stratégia része és a válság miatt 
2. ábra A kiskereskedelmi logisztikai stratégia fóbb elemeinek csoportositása

\begin{tabular}{|c|c|}
\hline Tipikus elemek & $\begin{array}{l}\text { - szállításszervezés } \\
\text { - beszerzés, rendelésmenedzsment } \\
\text { - rendelkezésre állás - készletezés, } \\
\text { raktározás } \\
\text { - csomagolás, egységképzés } \\
\text { - termékválaszték kialakítása }\end{array}$ \\
\hline $\begin{array}{l}\text { Ellátási lánchoz } \\
\text { kapcsolódó } \\
\text { elemek }\end{array}$ & $\begin{array}{l}\text { - beszálíitói rendszerek integrálása } \\
\text { - beszállítók hálózata } \\
\text { - outsourcing } \\
\text { - logisztikai szolgáltató menedzselése } \\
\text { - kommunikáció, információáramlás, } \\
\text { POS }\end{array}$ \\
\hline $\begin{array}{l}\text { Atipikus elemek } \\
\text { (kevés modellben } \\
\text { jelennek meg) }\end{array}$ & $\begin{array}{l}\text { - hiány } \\
\text { - reagálási képesség } \\
\text { • értékesítési pontok elhelyezése } \\
\text { - termékelhelyezés }\end{array}$ \\
\hline
\end{tabular}

Forrás: saját szerkesztés ezek okait a későbbi kutatások során kívánom feltárni. Feltételezhetően a magyar kiskereskedelemhez kapcsolódó ellátási láncok még nem egészen fejlettek ehhez az innovációhoz vagy nem tartják még szükségesnek - mindezek a nemzetközi trendekkel ellentétesek, hiszen a nemzetközi szakirodalom modelljei szinte minden esetben szorgalmazzák a tranzakció-alapú logisztikai folyamatokról történő áttérést a kapcsolatalapú logisztikára.

A megkérdezettek logisztikai stratégiájának tipizálásához vált leginkább fontossá, hiszen még inkább kiélezett a verseny.

Az outsourcing a megkérdezettek esetében többnyire nem jellemző (inkább a kiskereskedelmi láncok esetében van jelen, de nem minden esetben). Éppen ezért a logisztikai szolgáltató menedzselése sem képezi a logisztikai stratégiák részét a legtöbb esetben.

A termékválaszték kialakítása, beszerzésmenedzsment részben logisztikai kérdés, viszont a logisztikai stratégia fontos elemeként determinálják - a versenyképesség meghatározó eleme.

A raktározás szerepe leginkább az eladóterekbe helyeződik át, illetve a válság okozta általános készletszint csökkenés okán még inkább az eladótéri áruelhelyezés és tárolás válik meghatározóvá.

A beszállítói rendszerek átalakítása is fontos terület, leginkább a válság hatásaként jelenik meg új beszállítók kiválasztása illetve számuk változtatása is. Viszont a beszállítói rendszerek integrálása nem jellemző, mint ahogy a korszerü, real-time információáramlás irányába történő elmozdulás, az információ-megosztás sem (kivétel a POS eszközök használata). Mind- klaszteranalízist, szegmentumok létrehozását végeztem el (Jánosa, 2011). A klaszterek nem különböztethetőek meg boltméret, TEÁOR szám vagy tulajdoni/üzemeltetési forma szerint, hiszen körülbelül azonos összetételű mindhárom szegmens ezen tulajdonságok alapján.

A 3. táblázat összegzi a logisztikai stratégiák különböző gyakorlati megközelítéseit a szakirodalmi modell főbb elemei alapján. A logisztikai stratégiák tipizálása során a reagálási képesség, a változás- és válságkezelés tükrében vizsgálódtam, hiszen a hazai piacokon történő változások okán ez az egyik leginkább kritikus pontja a vállalati stratégiáknak is.

\section{KÖVETKEZTETÉSEK}

A nemzetközi szakirodalom alapján ismertetett kiskereskedelmi logisztikai szemléletek, modellek alapján vizsgált kiskereskedelmi egységek különböző trendeket követnek. A pull elvre történő átállás sajátossága a kiskereskedelemnek, azonban ez nem mondható el a kapcsolat-alapú logisztikai rendszerekre történő átállásról ez további kutatási irányt jelent. 


\section{3. táblázat A kiskereskedelmi logisztikai stratégiák tipizálása}

\begin{tabular}{|c|c|c|c|c|}
\hline & $\begin{array}{l}\text { „RÉSZBBEN } \\
\text { MEGÚJULÓ" }\end{array}$ & $\begin{array}{c}\text { „HAGYOMÁNYOS } \\
\text { ESZKÖZZ̈K” }\end{array}$ & $\begin{array}{l}\text { "LOGISZTIKAI } \\
\text { STRATÉGA" } \\
\end{array}$ & $\begin{array}{l}\text { besorolás a modell } \\
\text { elemei közé }\end{array}$ \\
\hline pull/push elv & inkább pull elv & push elv dominál & pull elv dominál & \\
\hline termékválaszték & $\begin{array}{l}\text { átalakítása forgási } \\
\text { sebesség alapján }\end{array}$ & $\begin{array}{l}\text { átalakítása kevés- } \\
\text { bé fontos }\end{array}$ & átalakítás fontos & $\begin{array}{l}\text { termék-választék } \\
\text { kialakítása }\end{array}$ \\
\hline forgási sebesség & fontos & kevésbé fontos & nagyon fontos & készletezés \\
\hline beszerzés & $\begin{array}{l}\text { nem jellemző az } \\
\text { olcsóbb termék }\end{array}$ & $\begin{array}{l}\text { nem jellemző az } \\
\text { olcsóbb termék }\end{array}$ & $\begin{array}{l}\text { árközpontú } \\
\text { beszerzés }\end{array}$ & beszerzés \\
\hline beszállítók & változatlan & változatlan & $\begin{array}{l}\text { részleges válto- } \\
\text { zások }\end{array}$ & beszállítók hálózata \\
\hline $\begin{array}{l}\text { beszerzés gyako- } \\
\text { risága }\end{array}$ & változatlan & változatlan & ritkább & beszerzés \\
\hline $\begin{array}{l}\text { készletnagyság } \\
\text { minimalizálása }\end{array}$ & $\begin{array}{l}\text { közepes mértékben } \\
\text { jellemző }\end{array}$ & elutasítva & nagyon fontos & készletezés \\
\hline $\begin{array}{l}\text { logisztikai meg- } \\
\text { oldások szerepe } \\
\text { a változás-me- } \\
\text { nedzsmentben }\end{array}$ & $\begin{array}{l}\text { közepes mértékben } \\
\text { fontos }\end{array}$ & legkevésbé fontos & nagyon fontos & reagálási képesség \\
\hline
\end{tabular}

Forrás: saját kutatás, $N=475$

Joia csoportosítása alapján az is kimondható, hogy a kiskereskedelmi egységek döntő része inkább kiskereskedelmi logisztikai stratégiát folytat, mintsem stratégiai logisztikát alkalmaz
- ez is további kutatási irányaim egyike. A kiskereskedelmi logisztika sajátosságai pedig rávilágítanak a magyar piacon történt válság okozta hatások következményeire és kezelésükre is.

Felhasznált irodalom:

[1.] Gudebus, T. and Brandes, T. (1997): Logistik: Kernkompetenz des Handels;Dynamik in Handel 1. pp. 71-72.

[2.] Farahani, R., Rezapour, S., Kardar, L. (2011): Logistics Operations and Management London: Elsevier

[3.] Fernie, J., Sparks, L. (2009): Logistics and Retail Management. London: Kogan Page

[4.] Gustafsson, K., Jönson G., Smith D., Sparks L. (2009): Retailing Logistics and Fresh Food Packaging Managing Change in the Supply Chain. London: Kogan Page

[5.] Jánosa, A. (2011): Adatelemzés SPSS használatával. Budapest: ComputerBooks Kiadó Kft.

[6.] Joia, A. L. (2003): IT-based management: Challenges and Solutions. Brazil: IGI Global. pp. 324.

[7.] Kotzab, H., Bjerre M. (2005): Retailing in a Scm-Perspective. Frederiksberg: Copenhagen Business School Press

[8.] Kotzab, H., Reutterer, T. (1999): Anforderungen an Logistik-systeme aus anwendersicht. In: Logistik management, Vol. 1, No. 3, 1999, p. 181-197.

[9.] Kotzab, H. and Schnedlitz, P. (1999): “Retailing, don't forget it in your Supply chain management concept", Journal für Betriebswirtschaft, No. 4, pp. 140-153.

[10.] Mulhern, F. (1997): Retail marketing: from distribution to integration. International Journal of Research and Marketing 17 (2) pp. 103-124.

[11.] Ray, R. (2010): Supply Chain Management for Retailing. New Delhi: Tata McGraw Hill Education Private Limited

[12.] Skjott-Larsen T., Schary P. B., Mikkola J. H., Kotzab H. (2007): Managing the Global Supply Chain. Denmark: Copenhagen Business School Press 